\title{
PENGARUH CUSTOMER VALUE DALAM MENINGKATKAN KEPUASAN WISATAWAN DI SAUNG ANGKLUNG UDJO \\ (Survei terhadap Wisatawan Nusantara Individu di Saung Angklung Udjo)
}

\author{
Sri Martina Intan Permatasari Hassan \\ Ridwan Purnama \\ Oce Ridwanudin \\ Manajemen Pemasaran Pariwisata FPIPS UPI
}

\begin{abstract}
Abstrak
Saung Angklung Udjo sebagai sanggar seni merupakan tempat laboratorium pendidikan, latihan, dan pertunjukan musik etnik untuk mendidik para pelatih dan pemain dalam bidang kesenian khas Jawa Barat, khususnya musik angklung. Dari pra penelitian yang telah dilakukan didapat permasalahan bahwa walaupun tingkat kunjungan di Saung Angklung Udjo tiap tahunnya selalu terjadi peningkatan tetapi masih saja ada pengunjung yang merasa tidak puas dengan pelayanan yang diberikan. Jenis penelitian yang digunakan adalah deskriptif verifikatif dan metode yang digunakan adalah explanatory survey dengan menggunakan skala ordinal. Teknik sampling yang digunakan adalah systematic random sampling dengan ukuran sampel menggunakan rumus slovin, maka diperoleh jumlah sampel sebanyak 100 responden. Teknik analisis data yang digunakan adalah regresi linier sederhana. Berdasarkan hasil perhitungan diperoleh persamaan regresi yaitu $Y=9,324+0,743 X$.
\end{abstract}

Kata kunci: customer value dan kepuasan

\section{PENDAHULUAN}

\subsection{Latar Belakang Penelitian}

Sebagai ikon kebanggaan masyarakat Jawa Barat dalam pengembangan seni dan budaya tradisi khususnya yang berbahan dasar bambu, tentunya Saung Angklung Udjo perlu memperhatikan bagaimana agar sebuah proses berkesenian dan transfer nilai budaya tradisi antar generasi tidak lantas padam begitu saja.

Dibalik tingkat kunjungan yang terus meningkat di tiap tahunnya, masih ada beberapa pengunjung merasa tidak puas dengan pelayanan Saung Angklung Udjo.

Dari pra penelitian tersebut dapat ditarik kesimpulan bahwa walaupun tingkat kunjungan di Saung Angklung Udjo tiap tahunnya selalu terjadi peningkatan tetapi masih saja ada wisatawan yang merasa tidak puas dengan pelayanan yang diberikan. Walaupun setelah dilihat dari hasil pra penelitian rata-rata wisatawan kurang puas pada bagian ticketing, hal ini tetap merupakan sebuah permasalahan yang tidak dapat dibiarkan. Selain itu, seluruh nilai skor masih dibawah skor ideal 150, oleh karena itu perlu untuk diperbaiki dan ditingkatkan kembali kualitas produk wisata yang ada, sehingga wisatawan merasa puas dan menyenangkan saat berkunjung ke Saung Angklung Udjo.

$$
\text { Kepuasan wisatawan sangat }
$$
bergantung kepada harapan pengunjung.
Oleh karena itu, strategi kepuasan wisatawan haruslah didahului dengan pengetahuan yang detail dan akurat terhadap harapan wisatawan. Karena itu perlu dilakukan strategi untuk meningkatkan kepuasan wisatawan, agar seluruh wisatawan yang datang ke Saung Angklung Udjo merasa puas dan akan kembali lagi untuk mengunjungi Saung Angklung Udjo dengan membawa serta kerabat dan temannya. Strategi yang diharapkan dapat mengatasi permasalahan kepuasan yang terjadi di Saung Angklung Udjo yaitu customer value (nilai pelanggan).

Berdasarkan latar belakang di atass, maka perlu diadakan penelitian untuk mengukur sejauh mana pengaruh customer value terhadap kepuasan wisatawan di Saung Angklung Udjo, maka peneliti tertarik untuk melakukan penelitian tentang "Pengaruh Customer Value dalam Meningkatkan Kepuasan Wisatawan di Saung Angklung Udjo" (Survei terhadap Wisatawan Nusantara Individu di Saung Angklung Udjo).

\subsection{Rumusan Masalah}

Adapun masalah yang akan dibahas pada penelitian ini sebagai berikut:

1. Bagaimana gambaran customer value di Saung Angklung Udjo

2. Bagaimana gambaran kepuasan wisatawan di Saung Angklung Udjo. 
3. Bagaimana pengaruh customer value terhadap kepuasan wisatawan di Saung Angklung Udjo.

\subsection{Tujuan Penelitian}

Adapun tujuan penulis mengadakan penelitian ini adalah untuk memperoleh temuan mengenai:

1. Gambaran customer value di Saung Angklung Udjo.

2. Gambaran kepuasan wisatawan di Saung Agklung Udjo.

3. Pengaruh customer value terhadap kepuasan wisatawan di Saung Angklung Udjo

\section{KAJIAN PUSTAKA}

\subsection{Customer Value}

Konsep nilai sangatlah penting terutama bagi keberhasilan pemasaran. Nilai merupakan sesuatu yang sangat berperan dalam pembentukan kepuasan pelanggan. Oleh karena itu, konsep penciptaan dan penambahan nilai memerlukan perhatian penuh dari manajemen. Isu yang paling mendasar ketika manajemen ingin menarik dan mempertahankan pelanggan adalah mengetahui dan memberikan nilai tambah bagi pelanggan. Setiap perusahaan harus mempelajari nilai dari sudut pandang pelanggan dan tidak berasumsi bahwa mereka mengetahui nilai apa yang berharga bagi pelanggan. Jumlah nilai bagi pelanggan ini bisa berupa nilai produk, nilai pelayanan dan nilai karyawan. Nilai produk misalnya kemenarikan pertunjukan yang ditampilkan, nilai pelayanan misalnya ketepatan dan kecepatan saat melayani pengunjung, dan nilai karyawan misalnya pengalaman, cara berpakaian dan cara berbicara saat berinteraksi dengan pengunjung.

Menurut Thamrin Abdullah dan Francis Tantri (2012:38), customer value adalah nilai terantar pada pelanggan adalah selisih antara nilai pelanggan total (total customer value) dan biaya pelanggan total (total customer cost). Dan nilai pelanggan total adalah sebundel manfaat yang diharapkan pelanggan dari barang/jasa tertentu. Menurut Kotler \& Keller (2012:125), menyebutkan customer value adalah perbedaan antara evaluasi calon pelanggan mengenai manfaat \& biaya dari sebuah penawaran dan alternatif yang dirasakan.

Jadi customer value dapat disimpulkan bahwa customer value (nilai pelanggan) adalah kumpulan manfaat yang diharapkan akan diperoleh pelanggan dari produk atau jasa tertentu setelah mengeluarkan pengorbanan.

\subsection{Kepuasan}

Menurut Bowie dan Buttle (2004:294), kepuasan pelanggan merupakan topik yang rumit. Beberapa perusahaan jasa menemui kesulitan untuk membuat garansi kepuasan pelanggan 100 persen mutlak.

Hal ini disebabkan karena kebutuhan dan keinginan pelanggan selalu mengalami perubahan dari waktu ke waktu. Jika pelanggan merasa puas, maka ada kecenderungan untuk melakukan pembelian ulang.

Satisfaction adalah kata dari bahasa Latin yang terbentuk dari kata satis yang berarti enough atau cukup, dan facere yang berarti to do atau melakukan. Jadi produk atau jasa yang bisa memuaskan adalah produk atau jasa yang sanggup memberikan sesuatu yang dicari oleh konsumen sampai pada tingkat cukup (Tony Sitinjak dkk, 2004:6).

Banyak perusahaan secara sistematis mengukur seberapa baik mereka memperlakukan pelanggan mereka, mengenali faktor-faktor yang membentuk kepuasan, dan melakukan perubahan dalam operasi dan pemasaran mereka sebagai akibatnya. Perusahaan akan bertindak bijaksana dengan mengukur kepuasan pelanggan secara teratur, karena salah satu kunci untuk mempertahankan pelanggan adalah kepuasan pelanggan.

\section{METODE PENELITIAN}

Metode pada penelitian pada dasarnya merupakan cara ilmiah untuk mendapatkan data dengan tujuan dan kegunaan memecahkan suatu masalah. Berdasarkan tujuan penelitian dan variabel-variabel yang diteliti maka jenis penelitian ini adalah penelitian deskriptif dan verifikatif. Berdasarkan jenis penelitian deskriptif dan verifikatif tersebut maka metode penelitian 
yang digunakan dalam penelitian ini adalah survey explanatory. Penelitian dengan menggunakan metode ini yaitu informasi dari sebagian populasi dikumpulkan langsung di tempat kejadian secara empiris dengan tujuan untuk mengetahui pendapat dari sebagian populasi terhadap objek yang sedang diteliti.
Sumber data adalah segala sesuatu yang dapat memberikan informasi mengenai data. Berdasarkan sumbernya data dibedakan menjadi dua, yaitu data primer dan data sekunder. Penelitian ini menggunakan data primer dan data sekunder yang selanjutnya dijelaskan pada Tabel 1 berikut.

\subsection{Jenis dan Sumber Data}

TABEL 3.1

JENIS DAN SUMBER DATA

\begin{tabular}{|l|l|l|l|}
\hline No & \multicolumn{1}{|c|}{ Data } & \multicolumn{1}{|c|}{ Sumber Data } & \multicolumn{1}{|c|}{ Jenis data } \\
\hline 1 & $\begin{array}{l}\text { Rekapitulasi wisatawan nusantara tahun } \\
2004-2012\end{array}$ & BPS & Data sekunder \\
\hline 2 & $\begin{array}{l}\text { Pertumbuhan kunjungan wisatawan ke } \\
\text { objek wisata } \\
\text { di provinsi Jawa Barat tahun 2006-2012 }\end{array}$ & Disbudpar Jawa Barat & Data sekunder \\
\hline 3 & $\begin{array}{l}\text { Data kunjungan wisatawan yang datang } \\
\text { ke kota Bandung }\end{array}$ & BPS Kota Bandung & Data sekunder \\
\hline 4 & $\begin{array}{l}\text { Fasilitas Saung Angklung Udjo } \\
\text { Data kunjungan wisatawan ke Saung } \\
\text { Angklung Udjo }\end{array}$ & $\begin{array}{l}\text { Corporate Secretary } \\
\text { Saung Angklung Udjo } \\
\text { Corporate Secretary } \\
\text { Saung Angklung Udjo }\end{array}$ & Data sekunder \\
\hline
\end{tabular}

\subsubsection{Populasi}

Sasaran populasi adalah populasi yang akan menjadi cakupan kesimpulan penelitian, jadi apabila dalam sebuah hasil penelitian dikeluarkan kesimpulan, maka menurut etika penelitian kesimpulan tersebut hanya berlaku untuk populasi yang telah ditentukan.

Berdasarkan penjelasan di atas, maka yang menjadi populasi dalam penelitian ini adalah para wisatawan nusantara individu yang berkunjung ke objek wisata Saung Angklung Udjo berdasarkan jumlah wisatawan nusantara Saung Angklung Udjo pada tahun 2012.

Berdasarkan data yang didapat pada Saung Angklung Udjo, jumlah keseluruhan wisatawan nusantara yang datang berkunjung ke Saung Angklung Udjo pada tahun 2012 sebanyak 176.858.

\subsubsection{Sampel}

Dalam penelitian tidak mungkin semua populasi diteliti, hal ini disebabkan karena keterbatasan dana, tenaga dan waktu. Maka penelitian diperkenankan mengambil sebagian objek populasi yang telah ditentukan, dengan catatan bagian yang diambil tersebut mewakili bagian yang lain yang diteliti. Menurut Sugiyono (2011:62) "Bila populasi besar, dan peneliti tidak mungkin mempelajari semua yang ada pada populasi, misalnya karena keterbatasan dana, tenaga dan waktu maka peneliti dapat menggunakan sampel yang diambil dari populasi itu". Berdasarkan dari perhitungan dengan menggunakan rumus slovin, ukuran sampel yang digunakan dalam penelitian ini adalah 100 .

\subsubsection{Validitas dan Realibilitas}

Berdasarkan hasil pengolahan data mengenai pengukuran validitas untuk variabel customer value menunjukkan bahwa item-item pertanyaan dalam kuesioner, karena skor $r_{\text {hitung }}$ lebih besar jika dibandingkan dengan $r_{\text {tabel }}$ yang bernilai 0,306. Pengukuran validitas menunjukkan nilai tertinggi sebesar 0,671 pada item 1 untuk pernyataan tingkat kualitas manfaat pertunjukan yang ditampilkan dibandingkan dengan pengorbanan yang dikeluarkan dan nilai terendah sebesar 0,357 pada item 6 untuk 
pernyataan tingkat pengetahuan karyawan mengenai produk pertunjukan dibandingkan dengan pengorbanan yang dikeluarkan.

Pengukuran validitas pada variabel kepuasan mendapat nilai tertinggi pada item 4 sebesar 0,721 dengan pernyataan tingkat kepuasan terhadap kecepataan pelayanan yang diberikan dibandingkan dengan pengorbanan yang dikeluarkan. Dan untuk nilai terendah 0,445 pada item 3 dengan pernyataan tingkat kepuasan terhadap pelayanan yang diberikan dibandingkan dengan pengorbanan yang dikeluarkan. Dan pada item 5 dengan pernyataan tingkat kepuasan terhadap kemenarikan penampilan karyawan dibandingkan dengan pengorbanan yang dikeluarkan.

Karena kuesioner yang digunakan bukan kuesioner yang baku, maka perlu di uji reliabilitasnya (keandalannya). Uji reliabilitas dalam penelitian ini menggunakan metode cronbanch. Koefisien Cronbach's Alpha merupakan statistik yang paling umum digunakan untuk menguji reliabilitas suatu instrumen penelitian. Suatu instrumen penelitian diindikasikan memiliki tingkat reliabilitas memadai jika koefisien Croanbach Alpha lebih besar atau sama dengan 0,70. Berdasarkan hasil uji reliabilitas, didapatkan semua nilai koefisien Croanbach Alpha di atas 0,70, dengan demikian alat ukur yang dipakai dalam penelitian ini memiliki keandalan yang baik.

\subsubsection{Pengujian Hipotesis}

Teknik analisis data yang digunakan dalam penelitian ini adalah metode analisis regresi linier sederhana. Analisis regresi linier sederhana digunakan untuk mendapatkan hubungan matematis dalam bentuk suatu persamaan antara variabel tak bebas tunggal dengan variabel bebas tunggal. Regresi linier sederhana hanya memiliki satu peubah $\mathrm{X}$ yang dihubungkan dengan satu peubah tidak bebas $\mathrm{Y}$.
Penelitian ini menggunakan data interval setelah menggunakan data ordinal seperti dijelaskan dalam operasionalisasi variabel sebelumnya, maka setelah data penelitian berskala interval selanjutnya akan ditentukan pasangan data variabel independen dari semua sampel penelitian.

Rancangan hipotesis dalam penelitian ini adalah:

Ho : $\rho=0$, artinya tidak terdapat pengaruh yang signifikan antara customer value terhadap kepuasan wisatawan nusantara individu Saung Angklung Udjo.

Ha : $\rho \neq 0$, artinya terdapat pengaruh yang signifikan antara customer value terhadap kepuasan wisatawan nusantara individu Saung Angklung Udjo.

\section{HASIL PENELITIAN DAN PEMBAHASAN}

\subsection{Customer Value}

Berdasarkan dari penelitian tanggapan wisatawan terhadap customer value terlihat indikator yang mendapatkan nilai tertinggi yaitu 12,9\% dengan skor 442 terdapat pada tiga pernyataan yaitu kualitas manfaat pertunjukan yang ditampilkan dibandingkan dengan pengorbanan yang dikeluarkan, kemenarikan pertunjukan yang ditampilkan dibandingkan dengan pengorbanan yang dikeluarkan, dan kesesuaian citra sebagai objek wisata budaya dibandingkan dengan pengorbanan yang dikeluarkan. Sedangkan yang mendapatkan nilai terendah terdapat pada pernyataan kecepatan pelayanan yang diberikan dibandingkan dengan pengorbanan yang dikeluarkan dengan nilai 11,5\% dan skor 393. Hal ini terjadi karena wisatawan merasa saat karyawan Saung Angklung Udjo melakukan pelayanan terhadap wisatawan dirasakan kurang cepat sehingga kadangkala terjadi antrian yang membuat wisatawan merasa tidak nyaman.

Secara keseluruhan tanggapan responden terhadap customer value Saung Angklung Udjo dapat diketahui kedudukannya berdasarkan data hasil 
rekapitulasi skoring, dimana nilai-nilai tersebut dibandingkan dengan kriteria nilai skor terendah yang didapat melalui perhitungan skor ideal (kriterium) dan skor terkecil, sehingga melalui skor standar tersebut dapat diketahui daerah kontinium yang menunjukan wilayah ideal dari variabel customer value.

Berdasarkan jumlah skor hasil perhitungan customer value adalah 3404. Dengan demikian customer value yang dilakukan oleh Saung Angklung Udjo adalah $3404 / 4000 \times 100 \%=85,1 \%$. Nilai 3404 termasuk dalam kategori interval "sangat tinggi". Jadi customer value yang dilakukan oleh Saung Angklung Udjo menurut penilaian wisatawan dalam kategori sangat tinggi atau sangat baik dengan persentase $85,1 \%$.

\subsection{Kepuasan}

Berdasarkan pada hasil penelitian tanggapan wisatawan terhadap kepuasan terlihat indikator yang mendapatkan nilai tertinggi yaitu $13,1 \%$ dengan skor 449 terdapat pada pernyataan kepuasan terhadap kesesuaian citra Saung Angklung Udjo sebagai objek wisata budaya dengan pertunjukan yang ditampilkan dibandingkan dengan pengorbanan yang dikeluarkan. Hal ini menunjukkan bahwa citra Saung Angklung Udjo sebagai objek wisata budaya telah memuaskan keinginan wisatawan untuk mendapatkan hiburan budaya yang berkualitas. Sedangkan yang mendapatkan nilai terendah terdapat pada pernyataan kepuasan terhadap kemenarikan penampilan karyawan dibandingkan dengan pengorbanan yang dikeluarkan dengan nilai $12,0 \%$ dan skor 414 karena wisatawan merasa bahwa penampilan karyawan kurang mengeluarkan ciri khas dari Saung Angklung Udjo tersebut.

Secara keseluruhan tanggapan responden terhadap kepuasan setelah mengunjungi Saung Angklung Udjo dapat diketahui kedudukannya berdasarkan data hasil skoring, dimana dapat diketahui daerah kontinium yang menunjukan wilayah ideal dari variabel kepuasan.
Berdasarkan jumlah skor hasil perhitungan kepuasan adalah 3435. Dengan demikian kepuasan berkunjung ke Saung Angklung Udjo adalah 3435/4000 x 100\% = $85,8 \%$. Nilai 3435 termasuk dalam kategori interval "sangat tinggi". Jadi kepuasan berkunjung ke Saung Angklung Udjo menurut penilaian wisatawan dalam kategori sangat tinggi atau sangat baik dengan persentase $85,8 \%$.

\subsection{Pengaruh Customer Value Terhadap Kepuasan}

Syarat pertama untuk melakukan analisis regresi adalah normalitas, sebagaimana yang diungkapkan oleh Triton (2005:76) bahwa data sampel hendaknya memenuhi prasyarat distribusi normal yaitu data yang akan dianalisis dengan statistic parametric harus mengikuti distribusi normal. Data yang mengandung data ekstrim biasanya tidak memenuhi asumsi normalitas. Jika sebaran data mengikuti sebaran normal, maka populasi dari mana data diambil berdistribusi normal dan akan dianalisis menggunakan analisis parametrik.
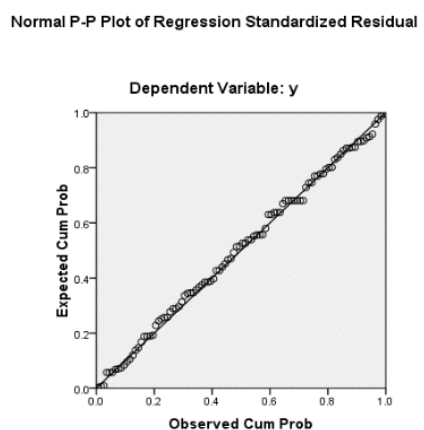

Sumber: Hasil Pengolahan Data 2013

GAMBAR 4.1

NORMAL PROBABILITY PLOT

Suatu model regresi layak dipakai apabila nilai residunya mengikuti distribusi normal, yaitu pada Gambar 2, dimana nilai residu berdistribusi normal apabila sebaran datanya terletak di sekitar garis diagonal yaitu dari kiri bawah ke kanan atas. Menurut Wahid Sulaiman (2004:88), untuk mendeteksi normalitas, digunakan Normal Probability Plot. Melalui plot ini, masingmasing nilai pengamatan dipasangkan dengan nilai harapan dari distribusi normal apabila sebaran data terletak di sekitar garis 
lurus yang melalui titik nol dan tidak mempunyai pola. Adapun histogram dependent variable kepuasan adalah sebagai berikut:

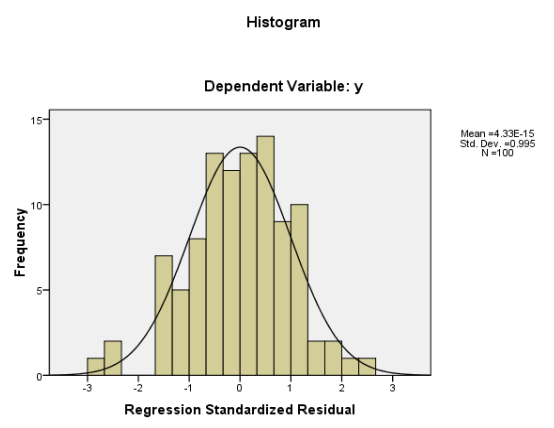

Sumber: Hasil Pengolahan Data 2013

GAMBAR 4.2

HISTOGRAM DEPENDENT VARIABLE KEPUASAN

Berdasarkan Gambar 3 terlihat bahwa model berdistribusi dengan normal, dikarenakan kurva berbentuk lonceng.

Heteroskedastisitas adalah varian residual yang tidak konstan pada regresi sehingga akurasi hasil prediksi menjadi meragukan. Residu pada heteroskedastisitas semakin besar apabila pengamatan semakin besar. Suatu regresi dikatakan tidak terdeteksi heteroskedastis apabila penyebaran nilai-nilai residual terhadap harga-harga prediksi tidak membentuk suatu pola tertentu (meningkat atau menurun).

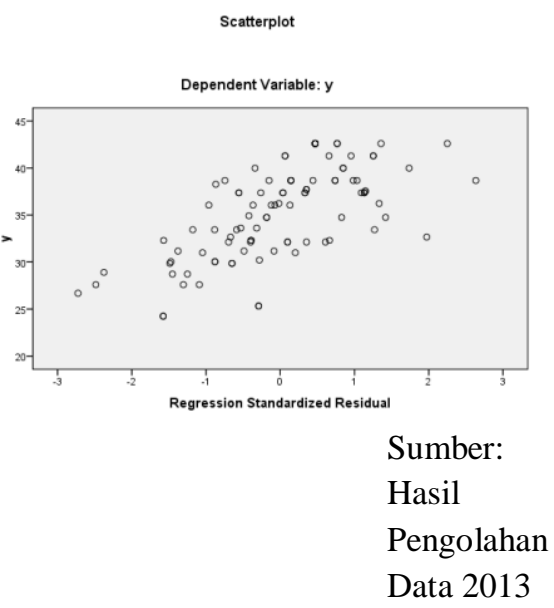

GAMBAR 4.3

UJI ASUMSI HETEROSKEDASTISITAS

Berdasarkan Gambar 4 maka dapat dilihat bahwa model penelitian tidak mempunyai gangguan heteroskedastisitas karena tidak ada pola tertentu pada grafik. Hal ini menunjukkan bahwa pada penelitian ini data yang digunakan sudah layak untuk meneliti kepuasan berkunjung ke Saung Angklung Udjo.

TABEL 4.1

\begin{tabular}{|l|l|r|r|c|}
\hline \multirow{2}{*}{$\begin{array}{c}\text { OUTPUT KOEFISIEN } \\
\text { REGRESIModel }\end{array}$} & \multicolumn{2}{|c|}{$\begin{array}{c}\text { Unstandardized } \\
\text { Coefficients }\end{array}$} & $\begin{array}{c}\text { Standardized } \\
\text { Coefficients }\end{array}$ \\
\cline { 3 - 5 } & \multicolumn{1}{|c|}{ B } & Std. Error & \multicolumn{1}{c|}{ Beta } \\
\hline 1 & (Constant) & 9.324 & 2.351 & \\
\cline { 2 - 5 } & Customer value & .743 & .066 & .749 \\
\hline
\end{tabular}

a. Dependent Variable: kepuasan

Berdasarkan nilai konstanta 9,324 dan untuk nilai customer value (X) sebesar 0,743 dengan nilai sig $=0,000$ yang berarti lebih kecil dari taraf signifikansi 0,05.

Hipotesis yang diuji yaitu customer value terhadap kepuasan (Y) dalam rangka pengambilan keputusan penerimaan dan penolakaan, hipotesis di tulis sebagai berikut:

Ho $=0$, artinya tidak terdapat pengaruh yang signifikan antara customer value terhadap kepuasan nusantara wisatawan individu Saung Angklung Udjo.

Ha $\neq 0$, artinya terdapat pengaruh yang signifikan antara customer value 
terhadap kepuasan wisatawan

nusantara individu Saung

Angklung Udjo.

Berdasarkan dari taraf signifikansi yang didapat yaitu 0,000 dibawah 0,05 , maka Ho ditolak dan Ha diterima, artinya customer value berpengaruh signifikan terhadap kepuasan.

Hasil analisis data dengan bantuan program SPSS 16 for windows diperoleh persamaan regresi sebagai berikut:

$$
\mathrm{Y}=\mathrm{a}+\mathrm{bX}
$$

Berdasarkan hasil perolehan data maka persamaan regresi untuk customer value adalah sebagai berikut:

$$
Y=9,324+0,743 X
$$

Keterangan :

$\mathrm{Y}=$ Kepuasan

$\mathrm{X}=$ Customer Value

Persamaan regresi linier sederhana di atas, diartikan nilai a constant adalah 9,324 Apabila customer value dinaikan satu satuan maka nilai kepuasan akan naik sebesar 0,743 . Koefisien pada persamaan regresi tersebut bernilai positif, artinya semakin baik customer value yang dilakukan di Saung Angklung Udjo, diprediksi akan semakin tinggi pula kepuasan.

\section{DAFTAR PUSTAKA}

Bowie, David and Buttle, Francis. 2004.

Hospitality Marketing: an Introduction. Amsterdam: Elsevier

Kotler, Philip and Keller. 2012. Marketing Management: 14th edition. New Jearsey: Pearson Prentice Hall

Sugiyono. 2011. Statistika untuk Penelitian. Bandung: Alfabeta

Thamrin Abdullah dan Francis Tantri. 2012. Manajemen Pemasaran. Jakarta:

Rajawali Pers

Tony Sitinjak, dkk. 2004. Strategi Menaklukan Pasar melalui Riset Ekuitas dan Prilaku Merek. Jakarta: PT. Gramedia 
